\title{
Investments in the Russian Agriculture Under the Economic, Political Volatility
}

\author{
Kuznetsov Nicolay Gennadevich \\ Rostov State University of Economics (RINH), Rostov on Don, Russia \\ Kuznetsov Vladimir Vasilevich, Soldatova Irina Yurevna \\ All-Russian Scientific Research Institute of Economy and regulations Russian Academy of Sciences, Rostov on Don, Russia
}

\begin{abstract}
The article states that the purpose of the agricultural industry of Russia is the creation of a market for innovation and investment to improve productivity and competitiveness in the context of growing economic, political, and natural climatic instability and volatility, both in Russia and abroad (membership in the WTO, industry globalization, etc.). Foreign economic and political sanctions have a growing negative impact. It is very important for the agriculture industry to be supported by the Russian state budget and to have administrative support, the institutional structure of the state, quantitative and qualitative indicators of national support: federal, regional, and municipal. Positive development of the regional and city aspect is also important.
\end{abstract}

Keywords: investments of the Russian agricultural economy, investment and innovative policy, government support of agriculture, investment of export and import of agricultural production

\section{Introduction}

Agriculture in Russia is one of the industries operating in the instable emerging market, with the overwhelming influence of risks: economic, political, natural, and climatic.

According to the scenario with a low level of risks, it is assumed that the effects of the crisis around the Crimea will be limited and short-lived, with the forecast growth of $1.1 \%$ in 2014 and $1.3 \%$ in 2015 . According to the scenario with a high level of risks in case deterioration in the geopolitical situation a more serious shock to the economic and investment activities is assumed. As a result in 2014 the forecast of economic downturn is to $1.8 \%$ and the gradual recovery of the economy in 2015 , with growth of $2.1 \%$... The preservation of significant risks is associated with the global situation, which will promote the conservation of high volatility markets. (World Bank, 2014, p. 24)

In 2013, less than a half of the key target indicators of the state program of development of agriculture from 2013 to 2020 were performed (Table 1).

\footnotetext{
Kuznetsov Nicolay Gennadevich, Doctor of Economics, professor, Prorector of Rostov State University of Economics (RINH), Rostov on Don, Russia.

Kuznetsov Vladimir Vasilevich, Academician of Russian Academy of Sciences, Doctor of Economics, professor, Chief Scientific Officer, All-Russian Scientific Institute of Economy and Regulations Russian Academy of Sciences, Rostov on Don, Russia.

Soldatova Irina Yurevna, Doctor of Economics, professor, Chief Researcher of All-Russian Scientific Research Institute of Economy and Regulations Russian Academy of Sciences, professor-consultant of Graduate School of Business in Southern Federal University, Rostov on Don, Russia.

Correspondence concerning this article should be addressed to Soldatova Irina Yurevna, fl. 90, pr. Kirovskiy 44, Rostov on Don, Russia 344022. E-mail: sold@aaanet.ru.
} 
Table 1

Performance of the State Program Development of Agriculture in 2013

\begin{tabular}{|c|c|c|c|c|}
\hline $\begin{array}{l}\text { Indicators of the state program for the development of } \\
\text { agriculture in } 20132012\end{array}$ & 2012 & $\begin{array}{l}\text { Target indicator of the } \\
\text { sate program }\end{array}$ & $\begin{array}{l}\text { Performance in } \\
2013\end{array}$ & $\begin{array}{l}\text { Ratio of } 2013 \\
\text { to } 2012(\%)\end{array}$ \\
\hline $\begin{array}{l}\text { The index of agricultural production in all categories of } \\
\text { farms }(\%)\end{array}$ & 95.2 & 102.2 & 106.2 & +4.0 \\
\hline Index of production crop production (\%) & 88.3 & 102.8 & 112.3 & +9.5 \\
\hline Index of production livestock products (\%) & 102.8 & 101.5 & 100.5 & -1.0 \\
\hline Index of production food, beverages (\%) & 105.1 & 103.0 & 101.0 & -2.0 \\
\hline $\begin{array}{l}\text { The profitability of the agricultural organizations } \\
\text { (including subsidies) (\%) }\end{array}$ & 12.1 & 13.0 & 9.3 & -3.7 \\
\hline $\begin{array}{l}\text { The volume index of investment in fixed capital in } \\
\text { agriculture (\%) }\end{array}$ & 100.6 & 104.0 & 96.0 & -8.0 \\
\hline Average monthly nominal wages in agriculture (rub) & $14,934.0$ & $14,100.0$ & $16,382.4$ & 116.2 \\
\hline
\end{tabular}

Gross domestic product of $8.5 \%$ in the Russian Federation belongs to the agriculture, $3.4 \%$ of fixed assets is concentrated in the industry. Agriculture employs more than 7.3 million people. Russia has one of the world's largest economic potential for the production of agricultural products $-8.9 \%$ of the world's arable lands, $2.6 \%$ of pasture, and $20 \%$ of the world reserves of water. The total amount of the federal budget for the implementation of the state program of agricultural development in 2013 is 107.6 billion rubles. Rubles of 97.9 billion will go directly to agricultural producers to support the production and social development of rural areas. A significant amount of funds is to be spent on maintenance of investment loans -59.8 billion rubles or $76 \%$.

A part of the subsidy will be allocated to new investment projects. The priority areas of investment are dairy and beef farming and poultry, as well as processing and storage of grain. More than half (54\%) of credits will be allocated to livestock breeding. The agriculture constitutes almost $4 \%$ in the value of GDP in the economy of the country, but has only $2.4 \%$ of the investment, and the share in total financial result of the economy is only $0.8 \%$. In the period of 2008 to 2014, the sector will need $\$ 70$ billion investment (Ushachev, 2014).

Modern agriculture has not managed to reach a stable high rate of technical and technological renovation, which is a prerequisite for innovation. The main reason for the slow pace of modernization of the agricultural sector is the low profitability of producers, most of whom are not able to carry out technical and technological modernization. This becomes a major constraint to the growth of labor productivity.

Russian agriculture is becoming more attractive for both Russian and foreign investors, but in recent years, the investment process has weakened due to economic and political reasons. The financial and economic crisis has affected the structure of the gross value added; the share of accumulation has decreased. The financial condition of agricultural organizations has deteriorated intensification of work to create favorable conditions to attract investment in innovation and the development of production due to crop failure in 2010 is needed. Political sanctions have become increasingly important. Russia, as a member of the WTO, is facing the increasing competition. To improve the competitiveness of agricultural products substantial investment in the productive capacity of the organizations, the formation of an adequate strategy of investment and innovation will be required.

Investments are to solve long-term and current problems: overcoming the crisis, the expansion of the tax base, increase of budget revenues, improving the competitiveness of Russian products, and accelerating diversification of Russian exports. Their influx is possible, only if the investors are sure that the federal and regional authorities understand the need for a targeted investment policy, linked with an adequate legal 
framework, take serious measures to improve the investment climate, and increase the inflow of foreign (primarily direct) through the extension of benefits and guarantees.

\section{Theoretical and Practical Awareness of Investment Support to the Russian Agriculture}

Features of formation of agrarian policy and strategy mechanism to attract investment in the industry are reflected in many works. Analysis of the methods of evaluation investment attractiveness and investment climate of individual enterprises and industries is given to many works.

Nevertheless, the lack of investment activity in agriculture and the need for investment monitoring of agricultural organizations and decision-making aimed at improving the investment attractiveness of the agricultural production have identified the need to continue scientific research on the improvement of existing and creation of new mechanisms to attract investment.

In Russian and foreign economic literature, there are different definitions of scientific concepts "investment", "innovation", and "competitiveness", for example, in the book called Agricultural Innovation Systems. An Investment Sourcebook, it is said:

The agricultural innovation system (AIS) approach has evolved from a concept into an entire sub-discipline, with principles of analysis and action; yet no detailed blueprint exists for making agricultural innovation happen at a given time, in a given place, for a given result. (World Bank, 2011)

The book called Agriculture Investment Sourcebook. Agriculture and Rural Development speaks on the concept of investing: Investments are the central pillar of the current rural policies of the World Bank to promote agricultural growth and poverty reduction. One of the main directions of the strategy outlines the priorities and approaches that the public sector, private sector, and civil society can use to increase the productivity and competitiveness of the agricultural sector so as to reduce rural poverty and sustain the natural resource base. These actions are a rich blend of science, technology, people, communication, management, training, research, capacity building, institutional development (World Bank, 2005).

There are five factors defining competitiveness pointed out by Porter (1993): rivalry among existing competitors, the threat of new competitors, the ability of buyers to bargain, the threat of substitutes of goods and services, and the ability of suppliers to bargain.

Porter (1993) identified five most common innovations that provide a competitive advantage: new technologies; new or changed customer demands; the emergence of a new segment of the market; changes in the value or availability of components of production; and change of government regulation.

Budgetary and administrative government support, namely, the institutional structure of the state, both quantitative and qualitative measures of national support: federal and regional, foreign economic support measures are particularly import in the field of innovation and investment to support of the agriculture. Investment is a tool in which you can put the money, hoping to maintain or increase their value, to ensure a positive value of income. If the government is interested in a stable and strong economy, it must create a favorable investment climate at the legislative and executive levels. Therefore, the question of investment in agriculture is a key one for the development of the competitiveness of the Russian economy.

\section{Features of Investment and Innovating Policy in Agriculture}

The main tasks of agriculture in Russia are: high dependence on food imports, Russia's membership in the WTO, a high degree of economic, political, natural, and climatic risks requires stronger competitiveness of 
production and the transition of agriculture to the innovative development model. This innovative model is constrained by the following factors:

(1) the lack of an effective system of innovation stimulating, effective transmission mechanism of science to production. There is a need for a comprehensive study of existing forms of state incentives to develop a set of scientifically based conceptual theoretical and practical proposals of state support for innovation;

(2) the decline in agricultural production, weak support from the state, and the high cost of innovation which do not allow to develop innovation. The innovative potential of agriculture is used by $40.6 \%$ against $50 \%$ or more compared to the developed countries. Forty to fifty percent of the completed scientific and technical developments annually remain unclaimed by the agricultural production (Altukhov, 2008).

(3) low sensitivity to domestic and foreign scientific and technological advances with increasing imports of food, agricultural machinery, equipment, means of protection, etc.. The level of scientific and technological development is $0.6 \%$, which is lower than that in the economy as a whole. Some sectors have taken the path of innovative development, but their production is exported, it is poultry farming, pig farming, and beet.

(4) non-equivalence of exchange agriculture with other sectors of the economy, leading to the degradation of its material and technical base. Agriculture reduces the opportunities for the integration of science and production, technological, organizational, and economic renewal of the industry. The situation is aggravated by rising energy prices. Innovation, without which it is impossible the implementation of innovative models of agricultural development is limited and available for a small part of the large farmers.

In the formation of the investment objectives of agricultural development, the structure of the innovation process must be carefully designed, the main components should be: large companies able to invest in research and development, to bring their results to production, modernize production; small business innovation with specific forms of financing, organization of services; state with a supportive legislative framework, science and technology policy both in Russia and abroad.

Russia has developed a strategy of innovative development of the agro-industrial complex in the period up to 2020 "Innovative Russia - 2020", the implementation of which will significantly increase the innovation and investment in agriculture (Ministry of Agriculture of the Russian Federation, 2011). A positive aspect is that the strategy provides an algorithm of state support of the innovation cycle.

The innovation cycle is a process associated with a sequence of transformations of innovation (scientific or entrepreneurial ideas) in products, technology, and business process, and launched on the market for commercial use. It consists of several interrelated steps: research and development, the development in the production, manufacture, and marketing. The strategy also contains measures aimed at reducing the administrative barriers to the spread of new technologies in the economy.

They are due to industry regulations, certification procedures, customs, and tax administration. The federal, regional, and municipal executive bodies are supposed to eliminate the practice of granting individual preferences, the creation of artificial barriers, the use of administrative resources. Transparency and openness of the procedures for the transfer of rights to state and municipal property, connection to electricity, gas networks, water and heating systems will be ensured.

Agriculture refers to the low-profit industry. This industry exists, thanks to government support, subsidies, and is characterized by extremely long investment cycle. In recent years, the situation in the industry is 
changing for the better. Firstly, due to government regulation and support of the industry, attraction of direct investments into it is growing. Secondly, investors have become more attentive to the agricultural industry, due to rising global food prices and the increasing importance of agriculture as a whole.

The one of the sources of investments financing in the fixed assets are the owners' funds. Thirty percent of equity investments belong to the owners' funds. Destabilizing factor for the growth of investment activity is the mismatch of the federal and regional legislation. Inefficient and cumbersome regulatory framework of the banking and currency regulation is also a big problem for investors. Currency regulation, presently carried out by the Bank of Russia, involves licensing the import of capital in full accordance with the Russian legislation, which often creates a prohibitive regime for foreign investment. Effective mechanisms to prevent the export of capital from the country are not developed.

Investment and innovation activity has specific traits in the agriculture: the seasonal nature and the relatively long cycle of agricultural production, the price disparity for the acquisition of industrial and sold agricultural products, a significant amount capital expenditure on land reclamation and improvement of land, which increases the cost of production and reducing the impact of investment.

SWOT analysis of agricultural production and the Russian foreign scientific experts (Russia Agribusiness Report, 2014) showed that in Table 2.

Table 2

SWOT Analysis of Agricultural Production In the Russian Federation

\begin{tabular}{|c|c|}
\hline Strong points & Weak points \\
\hline $\begin{array}{l}\text { (1) WTO as a legal, economic, and social base of the investment } \\
\text { support for agriculture. } \\
\text { (2) The Russian government maintains a strong parliamentary } \\
\text { majority and the overwhelming public support. } \\
\text { (3) Large resource base in Russia provides a solid foundation for } \\
\text { the internal and external investments. } \\
\text { (4) Export growth in the long term. }\end{array}$ & $\begin{array}{l}\text { (1) Agricultural regions of Russia are with a completely } \\
\text { different, positive, and negative characteristics, climatic } \\
\text { conditions, historically views and ways of agriculture. } \\
\text { (2) The vast majority of Russian regions is a zone of risky } \\
\text { agriculture. } \\
\text { (3) There is a lack of transparency in decision-making process, } \\
\text { including at the highest level. } \\
\text { (4) Activities of various influential groups unpredictable in } \\
\text { domestic politics in the long term. }\end{array}$ \\
\hline Possible sides & Threats \\
\hline $\begin{array}{l}\text { (1) Food Security Doctrine of Russia is as a deterrent of } \\
\text { investment growth. } \\
\text { (2) It restores the system of training and retraining of the } \\
\text { agricultural professionals. } \\
\text { (3) The Russian government continues to express its } \\
\text { commitment to the economic reforms. } \\
\text { (4) WTO membership will increase the incentive for the } \\
\text { authorities to implement stringent regulatory standards and } \\
\text { improve transparency. }\end{array}$ & $\begin{array}{l}\text { (1) Foreign food sanctions are as a deterrent of investment } \\
\text { growth. } \\
\text { (2) State, regional influence on business is growing. }\end{array}$ \\
\hline
\end{tabular}

Investment in the agriculture will be stronger if the state support of the industry will be properly maintained by the state and regional bodies. Regional system of state support of agriculture in Russia is becoming dominant in terms of the directions and volumes of financing. The effectiveness of regional policy is manifested in its flexibility, targeting, more control over the targeted use of budgetary funds. The absence of the above prerequisites at the federal level dramatically reduces the effectiveness of budget regulation of the budget funds. The analysis of the forms of state support for Russian investment is presented in the following Table 3. 
Table 3

Analysis of the Forms of the State Support of the Russian Agriculture

\begin{tabular}{|c|c|c|}
\hline Direct & Indirect & Mediated \\
\hline $\begin{array}{l}\text { Subsidies on agricultural production and } \\
\text { logistical resources, funding of the } \\
\text { interest rate on loans; subsidies for } \\
\text { compensation of costs of agricultural } \\
\text { producers; grants for capital } \\
\text { expenditure, etc.. }\end{array}$ & $\begin{array}{l}\text { Preferential taxation; purchases of } \\
\text { agricultural and food products for state } \\
\text { needs; procurement and commodity } \\
\text { interventions with grain; protection of } \\
\text { the producers' economic interests in the } \\
\text { foreign trade activity and others. }\end{array}$ & $\begin{array}{l}\text { Implementation of the various programs not } \\
\text { directly related to agricultural production; } \\
\text { participation in the activities of the branch } \\
\text { unions; implementation of programs of } \\
\text { regional engineering; implementation of } \\
\text { training programs and retain of the young } \\
\text { professionals in the agricultural areas, etc.. }\end{array}$ \\
\hline
\end{tabular}

\section{Conclusions}

In the concept of policy of agricultural support, investments of the Russian Federation should be modern understanding of the role of the state, consisting in actualization of the effectiveness of its impact on economic processes, supporting investment, and innovative activity of the industry in terms of economic, political, natural, and climatic volatility. The international sanctions amplify these risks. Accordingly, the important factors of the transition strategy for effective investment policy of the state should be:

- definition and structuring of investment and innovation goals of the policy within the current period, in the long term;

- the comparison with the actions of the state and the potential multiplier effect of regulation;

- evaluation of accounting of GDP in the agricultural sector with the growth of positive and negative influence of objective and subjective factors such as sanctions, nature, climate.

The current stage of the formation of public policy for the support for agriculture in Russia is characterized by the fact that agriculture production is forced to compete with products made in foreign countries with a high degree of budgetary support, which leads to the need to strengthen public investment support to agriculture in the country to create equal competitive conditions.

The strategy of the investment and innovation support of the state in Russia is based on a number of fundamental principles: active government support; combination of methods and tools of the market and state regulation of investment processes; establishing of the priority directions of the development of agriculture; validity of innovative development; development and improvement of information and advisory activities; and improving the competitive system of expertise and selection of innovative projects and programs taking into account the risks of economic, political, natural, and climatic.

Expansion of the investment activity of the agriculture is limited by the following factors: long-term return on investment associated with the production cycles; cumulative effects of chronic disparity in prices for the agricultural products and consumable material and technical resources; limited solvent demand for the products of the industry; uncontrolled growth of prices and tariffs for products and services of natural monopolies, transport costs, and others. Despite ongoing state activities aimed at improving the efficiency of agricultural production extremely unfavorable international sanctions, financial and economic conditions for the functioning of agriculture: the instability of the markets of agricultural products, raw materials and food; the absence of an insurance business risks in agricultural production; acute shortage of scientific production (research institutes, universities of agriculture) for highly qualified personnel are still a problem.

The most important area of investment policy in Russia is a regional perspective. The system of funding sources of state support for agriculture regional support system becomes dominant in the areas and volumes of 
financing. The effectiveness of regional policy is manifested in its flexibility, targeting more control over the targeted use of budgetary funds. The absence of these prerequisites at the federal level dramatically reduces the effectiveness of budget management budget. The concept of state support for the development of the region should be formed on the basis of the analysis of strengths, weaknesses, opportunities, and threats in the region (SWOT-analysis) can be realized through the development of targeted investment programs to support agriculture.

\section{References}

Altukhov, A. I. (2008). Innovative way of development of agriculture as the foundation to enhance its competitiveness (Bulletin Orel GAU).

Ministry of Agriculture of the Russian Federation. (2011). About the adoption of strategy of innovative development of the Russian Federation for the period till 2020 (the order of the Government of the Russian Federation of 08.12.2011 N 2227-p, Moscow).

Porter, M. (1993). International competition. In V. D. Shchetinin (Ed.), International relations.

Russia Agribusiness Report. (2014). Industry business environment overview (ISSN 1759-1678, Business Monitor International, UK).

Ushachev, I. G. (2014). Present state and problems of Russian agriculture (report by the Scientific Council RAS, 20.05.2014). Retrieved from http://www.vniiesh.ru/news/20579.html

World Bank. (2005). Agriculture investment sourcebook. Agriculture and rural development (34392, Agriculture Investment Sourcebook, Public Disclosure Authorized, Washington, D.C., USA , P. IX, 343920PAPER0Ag101OFFICIAL0USE0ONLY1.pdf).

World Bank. (2011). Agricultural innovation systems. An investment sourcebook overview (20433, Public Disclosure Authorized, Washington, D.C., USA , P. 1, WB_AIS_Sourcebook_Overview_web_final.pdf).

World Bank. (2014). The crisis of confidence exacerbates economic problems of Russia. Retrieved from http://www.worldbank.org/en/news/press-release/2014/03/26/russian-economic-report-31 